Original Research Paper

\title{
Responses of Grain Yield and Nutrient Accumulation to Water and Foliar Fertilizer Management in Upland and Wetland Rice Varieties
}

\author{
${ }^{1}$ Natdanai Juntakad, ${ }^{2}$ Sittichai Lordkaew, \\ ${ }^{1}$ Sansanee Jamjod and ${ }^{1,3}$ Chanakan Prom-u-thai \\ ${ }^{1}$ Agronomy Division, Department of Plant and Soil Sciences, Faculty of Agriculture, \\ Chiang Mai University, Chiang Mai 50200, Thailand \\ ${ }^{2}$ Center for Agricultural Resource System Research, Faculty of Agriculture, Chiang Mai University, \\ Chiang Mai 50200, Thailand \\ ${ }^{3}$ Lanna Rice Research Center, Chiang Mai University, Chiang Mai 50200, Thailand
}

Article history

Received: 23-03-2018

Revised: $15-05-2018$

Accepted: 24-05-2018

Corresponding Author:

Chanakan Prom-u-thai

Lanna Rice Research Center,

Chiang Mai University, Chiang

Mai 50200, Thailand

Email: chanakan15@hotmail.com chanakan.p@cmu.ac.th

\begin{abstract}
This study evaluated the effects of water and fertilizer managements on grain yield and nutrient accumulation in upland and wetland rice varieties. The two rice varieties representing upland $(\mathrm{KH}$ $\mathrm{CMU}$ ) and wetland (CNT1) ecotypes were grown in different water conditions and fertilizer managements. The interaction between variety and water condition had significantly affected on grain yield and straw dry weight. The water condition and fertilizer management were also affected on grain nutrient concentrations differently between the two varieties. The difference in responses to grain nutrients between the two rice varieties representing their original ecotypes of wetland and lowland is the key factor with respect to the proper management of water and fertilizers in order to maximize in both grain yield and nutrition. This knowledge is useful for the proper management of water and fertilizers for improving grain yield and nutrient accumulation. However, increasing the number of rice varieties in each upland and wetland ecotypes is needed to confirm the responses to water and fertilizer management in the future study.
\end{abstract}

Keywords: Rice Ecotype, Upland Rice, Wetland Rice, Foliar Fertilization, Aerobic Condition

\section{Introduction}

Nitrogen $(\mathrm{N})$, Phosphorus $(\mathrm{P})$ and potassium $(\mathrm{K})$ are the common macronutrient fertilizers used by farmers to improve rice crop production. In Bangladesh, applying of $87 \mathrm{~kg} \mathrm{~N}, 20 \mathrm{~kg} \mathrm{P}$ and $25 \mathrm{~kg} \mathrm{~K} \mathrm{ha}^{-1}$ in rice crops increased grain yield from $3.6 \mathrm{t} \mathrm{ha}^{-1}$ with no fertilizer application to $7.5 \mathrm{t} \mathrm{ha}^{-1}$ due to improving of plant height, number of tillers and panicles per hill and grains per panicle (Islam et al., 2011). This has also been observed in China where N, P and $\mathrm{K}$ fertilizer application was found to increase grain yield by 10.1 , 5.0 and $8.6 \%$, respectively, compared with no fertilizer application ( $\mathrm{Xu}$ et al., 2016). Direct broadcasting of fertilizers in the crop soil is the practice followed by farmers which has effect on the transport and movement of nutrients from the soil solution into plants and effectively improved crop yield (Moraghan and
Mascagni, 1991; Comerford, 2005). On the other hand, foliar fertilizer application is an alternative fertilizer application in rice by spraying the fertilizer directly onto the leaf, especially in the case of micronutrients in which the nutrients are diffused through the cuticle, then transported through the cell wall by passive transport and finally move through the plasma membrane by active transport to enter the plant cell (Fageria et al., 2009). This technique has been reported as an efficient method as it allows the absorption to occur rapidly into the inner cell layers of the leaf and other reproductive organs (Ahmad and Jabeen, 2005; Ganapathy et al., 2008), which consequently results in an increase in both the quality and quantity of production, reduce in the loss of nutrients (Tejada and Gonzalez, 2004) and rapidly bringing a solution to the problem of nutrient deficiency caused by soil fertilizer application due to highly acidic or alkaline condition 
(Xiang et al., 2009). Recently, foliar fertilizer application was found to be suitable not only in the case of micronutrients but also macronutrients as it has been reported that foliar application of $\mathrm{N}, \mathrm{P}$ and $\mathrm{K}$ after the flowering stage improved $10 \%$ grain yield of rice due to improvement in the grain-filling percentage and the grain weight when compared with no foliar fertilizer treatments (Cruz et al., 2012). In addition, foliar application of $\mathrm{N}$ fertilizer in rice has been reported to have resulted in $4 \%$ increase in the grain yield, $5 \%$ increase in the grain starch concentration and $22 \%$ increase in the grain protein concentration as it improved the photosynthesis rate (Tejada and Gonzalez, 2004). Thus, foliar fertilizer application may not be able to completely replace soil fertilization, but it is a way to promote the efficiency of nutrient absorption into plant cells, which would certainly have an effect on grain yield and quality in rice crops. However, most reports have been focusing only on foliar fertilizer application in the wetland rice crops grown under waterlogged conditions, while there are no reports available on the responses of grain yield and quality to foliar fertilizer application as compared between wetland and upland rice varieties which are originally different in their ecotype systems. Upland rice is grown in the aerobic conditions with naturally well drained soils and low availability of nutrients, while wetland rice is grown in flooded conditions where oxygen $\left(\mathrm{O}_{2}\right)$ becomes the limiting factor for root functions such as uptake of ions (Yoshida, 1981; Marschner, 2012). In this study, the KH CMU and CNT1 were selected as representatives of upland and wetland rice varieties, respectively. The responses of grain yield and nutrient accumulation between these different rice ecotype varieties to water conditions and fertilizer managements were expected differently. The results of this study would be useful for proper management of fertilizers in rice fields to increase productivity, improve grain quality and reduce nutrient deficiency in upland and wetland rice varieties grown in different conditions.

\section{Materials and methods}

The pot experiment was conducted during the wet season (June-December) in 2017 at Chiang Mai University, Thailand, during the period from July 2016 to September 2017. The experiment was arranged in factorial combination based on a randomized complete block design with three independent replications.

\section{Plant culture}

Two rice varieties (CNT1, wetland rice and $\mathrm{KH}$ CMU, upland rice) were used in this study. The rice plants were grown in two different water conditions (flooded and aerobic) and four fertilizer managements (Table 1). Seeds of both the varieties were germinated in plastic glasses for 7 days. The seedlings were then transplanted into a cement pot with $0.8 \mathrm{~m}$ in diameter and $0.4 \mathrm{~m}$ in height, with approximately $0.50 \mathrm{~m}^{2}$ of pot surface area. A single seedling was planted with $0.2 \times 0.2 \mathrm{~m}$ spacing between hills. In the waterlogged condition, water was maintained about $10 \mathrm{~cm}$ above soil surface throughout the experiment, while in the aerobic conditions was manually provided water at about field capacity twice daily. The fertilizers nitrogen (urea), phosphorus (sodium dihydrogen orthophosphate) and potassium (potassium chloride) were applied directly into the soil in all the treatments at three stages (tillering, booting and flowering), while foliar fertilization of $\mathrm{N}, \mathrm{P}$ and $\mathrm{K}$ in similar form as above was carried out in four stages (tillering, booting, heading and flowering). The details of fertilizer application are given in a (Table 1). The solution was prepared by dissolving powders of the fertilizer in Triple Distilled Deionized (TDI) water. The prepared solution was poured into a sprayer. The foliar application was carried out by evenly spraying the solution until all of the plants were wet and the solution just began to drip from the leaves, in the morning around 10 o'clock. The rates of application were 280, 640 and $220 \mathrm{ml} \mathrm{m}^{-2}$ for $\mathrm{N}, \mathrm{P}$ and $\mathrm{K}$, respectively. The soil used in this study was sandy loam, having $\mathrm{pH} 5.8$, $1.38 \%$ organic matter, $0.07 \%$ total nitrogen, $35.06 \mathrm{mg}$ $\mathrm{kg}^{-1}$ available phosphorous and $39.87 \mathrm{mg} \mathrm{kg} \mathrm{kg}^{-1}$ exchangeable potassium.

\section{Sample Collection and Preparation}

The samples were harvested at maturity. Thereafter, the grain yield, straw yield and yield components were evaluated. The subsample of $50 \mathrm{~g}$ unhusked rice grains was dehusked manually to avoid micronutrient contamination to yield brown rice before it was subjected to oven drying at $70^{\circ} \mathrm{C}$ for $72 \mathrm{~h}$.

\section{Nutrient Analysis}

Samples of brown rice grains were analyzed for $\mathrm{N}$ concentration by Kjeldahl method (Bremner and Mulvaney, 1982). P concentration by vanado-molybdate method (Watanabe et al., 1998) and $\mathrm{K}, \mathrm{Fe}$ and $\mathrm{Zn}$ concentrations by using an atomic absorption spectrophotometer (A A) (Delhaiz et al., 1984) after the dry ashing procedure.

\section{Statistical Analysis}

Analysis of significant difference was conducted by analysis of variance (ANOVA), the different means of the data at $p<0.05$ were compared by the Least Significant Difference (LSD). The correlation coefficients was examined by Pearson's correlation analysis. 
Table 1: Description of growing condition with different water conditions and fertilizer managements in two rice varieties

\begin{tabular}{lll}
\hline Water condition & Fertilizer management & Symbol \\
\hline Flooded & Local treatment & \\
& Nitrogen, phosphorus and potassium fertilizers were directly \\
& applied into soil at $6.8,15.8$ and $5.2 \mathrm{~g} \mathrm{pot}^{-1}$, respectively. \\
& Local treatment + Foliar $0.5 \%$ nitrogen & \\
& Local treatment + Foliar $0.5 \%$ phosphorus & \\
& Local treatment + Foliar $0.5 \%$ potassium & \\
& Local treatment & Foliar P \\
Aerobic & Nitrogen, phosphorus and potassium fertilizers were directly \\
& applied into soil at $6.8,15.8$ and 5.2 g pot ${ }^{-1}$, respectively. \\
& Local treatment + Foliar $0.5 \%$ nitrogen \\
& Local treatment + Foliar $0.5 \%$ phosphorus \\
& Local treatment + Foliar $0.5 \%$ potassium \\
&
\end{tabular}

\section{Results}

\section{Grain Yield and Straw Dry Weight}

There was a significant interaction effect between rice variety and water condition on grain yield and straw dry weight $(p<0.05)$ (Table 2$)$. The variety CNT1 had an average grain yield at $19.5 \mathrm{~g} \mathrm{plant}^{-1}$ without the effect from water condition. The similar grain yield was found in $\mathrm{KH} \mathrm{CMU} \mathrm{grown} \mathrm{in} \mathrm{the} \mathrm{aerobic} \mathrm{condition,} \mathrm{but} \mathrm{about}$ $32 \%$ grain yield was decreased when grown in the flooded condition. The straw dry weight of CNT1 was dominantly higher than in KH CMU which was slightly decreased from the aerobic to flooded condition in CNT1, while almost half was decreased in KH CMU. However, no effect of fertilizer management was observed on both grain yield and straw dry weight.

\section{Grain Nutrient Accumulation}

The grain $\mathrm{N}, \mathrm{P}$ and $\mathrm{K}$ concentrations were affected differently by rice variety, water condition and fertilizer management. The interaction effect between rice variety and fertilizer management and between water condition and fertilizer management was found on grain $\mathrm{N}$ concentration $(\mathrm{p}<0.05)$ (Fig. $1 \mathrm{~A}, \mathrm{~B})$. In KH CMU, foliar $\mathrm{N}$ did not effect on grain $\mathrm{N}$, but it improved $13 \%$ of grain $\mathrm{N}$ concentration from the control treatment in CNT1. On the other hand, foliar $\mathrm{N}$ in the aerobic condition was found to have $12 \%$ higher grain $\mathrm{N}$ than the control treatment, while the effect was not found in the flooded condition. The variety KH CMU was found to have higher both grain $\mathrm{P}$ and $\mathrm{K}$ concentrations than in CNT1 (Fig. 1C, D). In KH CMU, both treatments of with and without foliar $\mathrm{P}$ in the flooded condition had grain $\mathrm{P}$ concentrations higher than those in the aerobic condition, while water condition and fertilizer management had no effect on grain P in CNT1 (Fig. 1C).

Foliar $\mathrm{N}$ treatment was carried out to analyze grain $\mathrm{Fe}$ and $\mathrm{Zn}$ concentration in comparison with the control treatment. Grain Fe was significantly affected by the interaction between variety and fertilizer management and between water condition and fertilizer management $(\mathrm{p}<0.05)$ (Fig. 2A, B). The concentration of $\mathrm{Fe}$ in $\mathrm{KH}$ CMU was higher than in CNT1 and it was not affected by foliar $\mathrm{N}$, while foliar $\mathrm{N}$ increased $14 \%$ of grain $\mathrm{Fe}$ from the control treatment in CNT1. On the other hand, foliar $\mathrm{N}$ in the aerobic condition resulted in the highest grain $\mathrm{Fe}$, while the lowest was found when foliar $\mathrm{N}$ in the flooded condition. The concentration of $\mathrm{Zn}$ had affected by the interaction between the three factors. In $\mathrm{KH} \mathrm{CMU}$, grain $\mathrm{Zn}$ was not affected by water condition and fertilizer management, but foliar $\mathrm{N}$ in the aerobic condition had about $20 \%$ grain $\mathrm{Zn}$ higher than the other treatments 164 in CNT1 (Fig. 2B).

Grain $\mathrm{N}$ content was significantly affected by rice variety and fertilizer management, while rice variety dominantly affected on grain content of $\mathrm{P}$ and $\mathrm{K}$ $(\mathrm{p}<0.05)$ (Table 3). CNT1 had about $21 \%$ higher grain $\mathrm{N}$ content than in $\mathrm{KH} \mathrm{CMU}$, while around the similar percentage of grain $\mathrm{N}$ content was increased from the flooded to aerobic condition. CNT1 had about 19\% grain $\mathrm{P}$ content higher than KH CMU, but the opposite result was observed in grain $\mathrm{K}$ content. Grain Fe content had significantly affected by both water condition and fertilizer management, while grain $\mathrm{Zn}$ content had affected by fertilizer management $(\mathrm{p}<0.05)$ (Table 4). The higher grain Fe content was found when rice was grown in the aerobic condition compared with flooded condition and foliar $\mathrm{N}$ had higher grain $\mathrm{Fe}$ and $\mathrm{Zn}$ content than the control treatment.

\section{Correlation Between Grain Yield and Nutrient Concentration}

The correlation analysis between the grain yield and the grain nutrient concentration was different between the two rice varieties (Table 5). In KH CMU, the grain yield was significantly negative correlated with the grain $\mathrm{N}$ concentration $(\mathrm{r}=-0.62, \mathrm{p}<0.05), \mathrm{P}$ concentration $(\mathrm{r}=$ - 0.88, $\mathrm{p}<0.05)$ and $\mathrm{Zn}$ concentration $(\mathrm{r}=-0.77, \mathrm{p}<0.05)$ and positively correlated with the grain $\mathrm{Fe}$ concentration $(\mathrm{r}=0.93, \mathrm{p}<0.05)$. In CNT1, the positive correlation between grain yield and grain $\mathrm{P}$ concentration was also found $(r=0.72, p<0.05)$. 
Table 2: Grain yield and straw dry weight of two rice varieties grown under different water conditions and fertilizer managements

\begin{tabular}{llll}
\hline Variety & Water condition & Grain yield (g plant $\left.{ }^{-1}\right)$ & Straw dry weight $(\mathrm{g}$ plant \\
\hline CNT1 & Flooded & $19.4 \mathrm{a}$ & $30.6 \mathrm{~b}$ \\
& Aerobic & $19.7 \mathrm{a}$ & $34.5 \mathrm{a}$ \\
KH CMU & Flooded & $11.8 \mathrm{~b}$ & $12.8 \mathrm{~d}$ \\
& Aerobic & $17.4 \mathrm{a}$ & $21.2 \mathrm{c}$ \\
F-test & & $* *$ & $* *$ \\
Variety (V) & & $* *$ & $* *$ \\
Water condition (W) & & $\mathrm{ns}$ & $\mathrm{ns}$ \\
Fertilizer management (F) & $*$ & $*$ \\
V x W & & $\mathrm{ns}$ & $\mathrm{ns}$ \\
V x F & $\mathrm{ns}$ & $\mathrm{ns}$ \\
W x F & $\mathrm{ns}$ & $\mathrm{ns}$ \\
V x W x F & & &
\end{tabular}

Note: "*” and "**" denote "significant difference at $\mathrm{p}<0.05$ and $\mathrm{p}<0.01$, respectively," and "ns" indicates "no significant difference." Different lowercase letter indicate significant difference within each column at $\mathrm{p}<0.05$

\begin{tabular}{l} 
Table 3: Grain N, P and K content in brown rice of two varieties grown under different water and fertilizer managements \\
\hline $\mathrm{N}$
\end{tabular}

\begin{tabular}{|c|c|c|c|c|}
\hline Variety & Water condition & $\begin{array}{l}\mathrm{N} \\
\left(\mathrm{mg} \mathrm{plant}^{-1}\right)\end{array}$ & $\begin{array}{l}\mathrm{P} \\
\left(\mathrm{mg} \mathrm{plant}^{-1}\right)\end{array}$ & $\begin{array}{l}\mathrm{K} \\
\left(\mathrm{mg} \mathrm{plant}^{-1}\right)\end{array}$ \\
\hline CNT1 & & 344.9 A & $80.5 \mathrm{~A}$ & $42.4 \mathrm{~B}$ \\
\hline KH CMU & & $271.7 \mathrm{~B}$ & $65.1 \mathrm{~B}$ & $54.0 \mathrm{~A}$ \\
\hline & Flooded & $271.5 \mathrm{~b}$ & & \\
\hline & Aerobic & $345.1 \mathrm{a}$ & & \\
\hline \multicolumn{5}{|l|}{ F-test } \\
\hline Varieties $(\mathrm{V})$ & & $* *$ & $*$ & $*$ \\
\hline Water condition $(\mathrm{W})$ & & ns & ns & ns \\
\hline Fertilizer management $(\mathrm{F})$ & & $*$ & ns & ns \\
\hline $\mathrm{V} \times \mathrm{W}$ & & ns & ns & ns \\
\hline $\mathrm{V} \times \mathrm{F}$ & & ns & ns & ns \\
\hline $\mathrm{W} \times \mathrm{F}$ & & ns & ns & ns \\
\hline $\mathrm{V} \times \mathrm{W} \times \mathrm{F}$ & & ns & ns & $\mathrm{ns}$ \\
\hline
\end{tabular}

Note: "*” and “**" denote "significant difference at $\mathrm{p}<0.05$ and $\mathrm{p}<0.01$, respectively," and "ns" indicates "no significant difference."

Different lowercase letter indicate significant difference within each column at $\mathrm{p}<0.05$

Table 4: Grain Fe and $\mathrm{Zn}$ content in brown rice of two varieties grown under different water and fertilizer managements

\begin{tabular}{llll}
\hline Water condition & Fertilizer management & $\begin{array}{l}\mathrm{Fe} \\
\left.(\mathrm{mg} \mathrm{plant})^{-1}\right)\end{array}$ & $\begin{array}{l}\mathrm{Zn} \\
(\mathrm{mg} \mathrm{plant})\end{array}$ \\
\hline Flooded & & $0.35 \mathrm{~B}$ & - \\
Aerobic & Control & $0.48 \mathrm{~A}$ & - \\
& Foliar N & $0.37 \mathrm{~b}$ & $0.64 \mathrm{~b}$ \\
& & $0.46 \mathrm{a}$ & $0.78 \mathrm{a}$ \\
F-test & & \\
$(\mathrm{p}<0.05)$ & Varieties (V) & $\mathrm{ns}$ & $\mathrm{ns}$ \\
& Water condition (W) & $* *$ & $\mathrm{~ns}$ \\
& Fertilizer management (F) & $*$ & $\mathrm{~ns}$ \\
& $\mathrm{~V} \times \mathrm{W}$ & $\mathrm{ns}$ & $\mathrm{ns}$ \\
& $\mathrm{V} \times \mathrm{F}$ & $\mathrm{ns}$ & $\mathrm{ns}$ \\
& $\mathrm{W} \times \mathrm{F}$ & $\mathrm{ns}$ & $\mathrm{ns}$ \\
\hline
\end{tabular}

Note: "*” and "**" denote "significant difference at $\mathrm{p}<0.05$ and $\mathrm{p}<0.01$, respectively," and "ns" indicates "no significant difference."

Table 5: Correlation analysis of grain yield $\left(\mathrm{g} \mathrm{pot}^{-1}\right)$ and concentration of $\mathrm{N}, \mathrm{P}, \mathrm{K}, \mathrm{Fe}$ and $\mathrm{Zn}$ in grains of two rice varieties grown under different water and fertilizer managements

\begin{tabular}{lccccc}
\hline Variety & $\mathrm{N}(\%)$ & $\mathrm{P}(\%)$ & $\mathrm{K}(\%)$ & $\mathrm{Fe}\left(\mathrm{mg} \mathrm{kg}^{-1}\right)$ & $\mathrm{Zn}\left(\mathrm{mg} \mathrm{kg}^{-1}\right)$ \\
\hline CNT1 & $0.39 \mathrm{~ns}$ & $0.72^{* *}$ & $-0.04 \mathrm{~ns}$ & $-0.34 \mathrm{~ns}$ & $-0.31 \mathrm{~ns}$ \\
KH CMU & $-0.62^{*}$ & $-0.88^{* *}$ & $-0.19 \mathrm{~ns}$ & $0.93^{* *}$ & $-0.77^{* *}$ \\
\hline
\end{tabular}

Note: "*" and "**" denote "significant difference at $\mathrm{p}<0.05$ and $\mathrm{p}<0.01$, respectively," and "ns" indicates "no significant difference." Different lowercase letter indicate significant difference within each column at $\mathrm{p}<0.05$. 


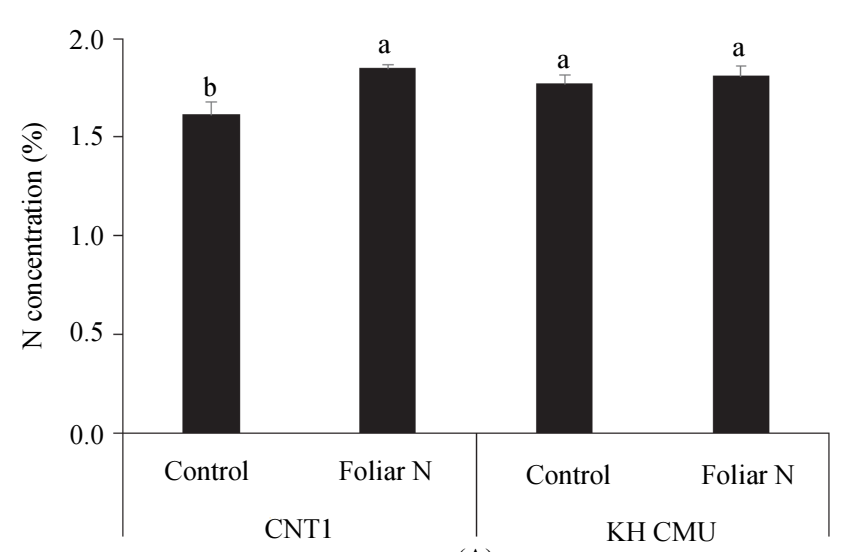

(A)

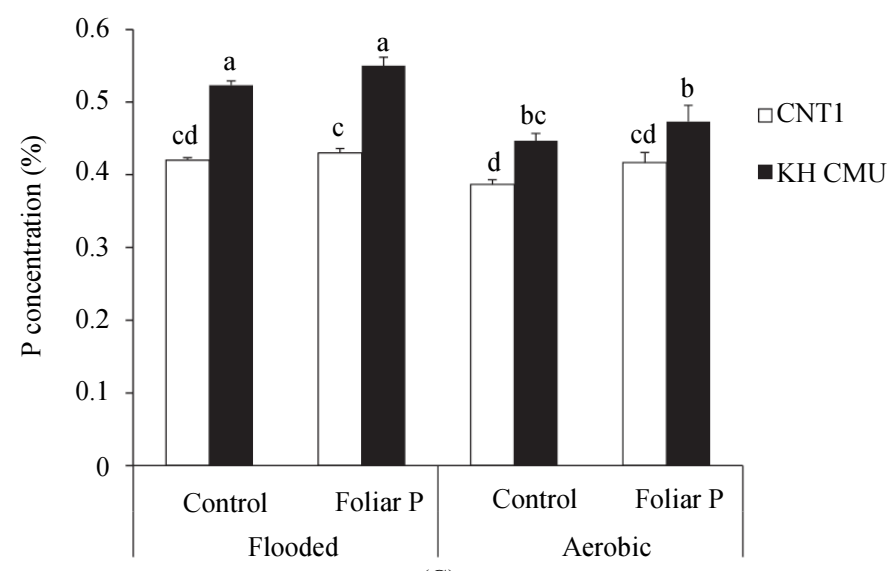

(C)

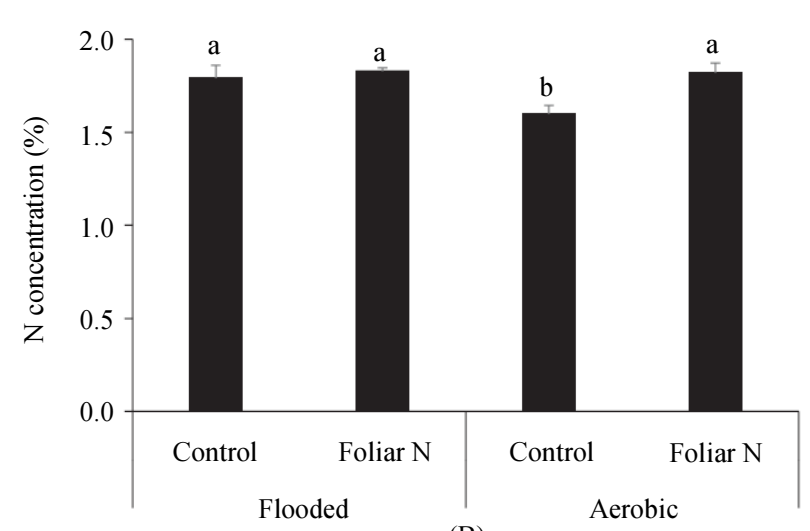

(B)

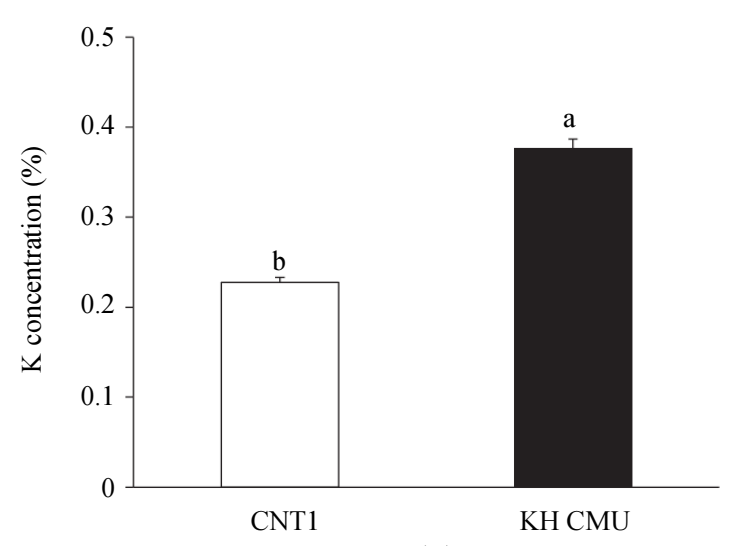

(D)

Fig. 1: The concentrations of nitrogen (A, B), phosphorus (C) and potassium (D) in brown rice grain of two varieties grown under different water conditions and fertilizer managements

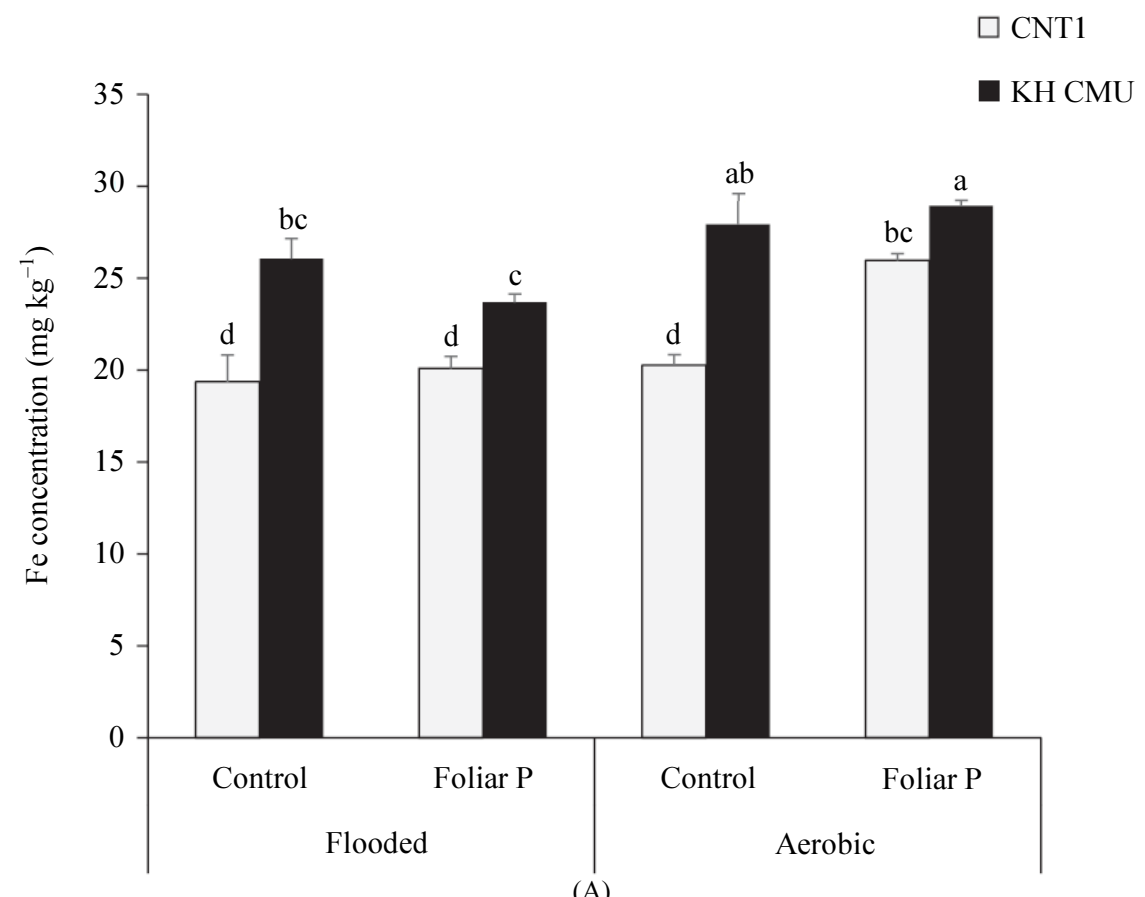




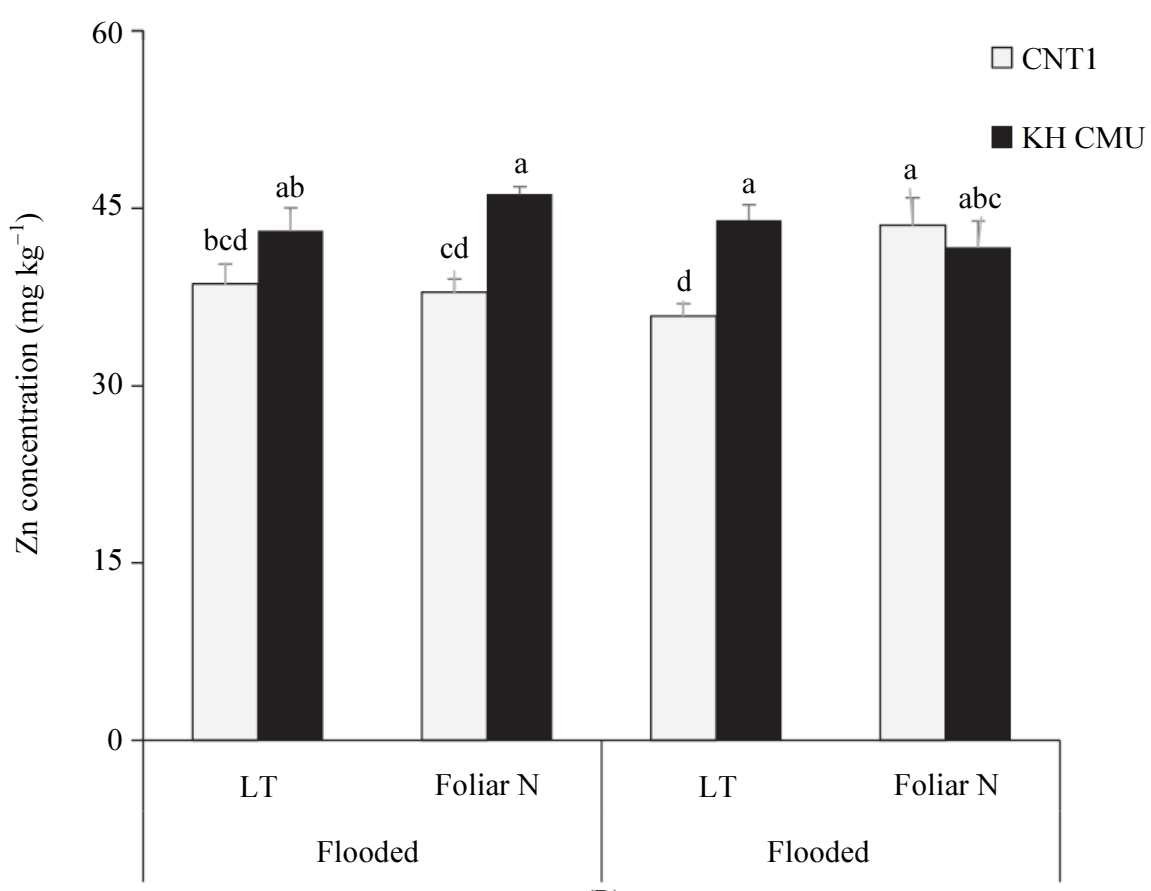

(B)

Fig. 2: The concentrations of iron (A) and zinc (B) in brown rice grain of two varieties grown under different water conditions and fertilizer managements

\section{Discussion}

Rice varieties are commonly characterized into upland and wetland types by their original ecosystem. The upland rice variety is grown in aerobic conditions, naturally well drained soils and low availability of several nutrients such as $\mathrm{N}, \mathrm{P}, \mathrm{K}, \mathrm{Fe}$ and $\mathrm{Zn}$ is observed while, the wetland rice variety is grown in flooded conditions where oxygen $\left(\mathrm{O}_{2}\right)$ becomes the limiting factor for root functions such as uptake of ions (Marschner, 2012; Yoshida, 1981). This study has shown that grain yield and straw dry weight are independent of the fertilizer management, but dependent on the interaction effect between variety and water condition. The traditional upland rice variety (KH CMU) had 32\% and $39 \%$ grain yield and straw dry weight in the aerobic condition higher than in the flooded condition, respectively, but the effect was not showed in the modern improved rice variety (CNT1). This evident confirmed that the rice varieties could adapt well to their growing condition to fulfill the nutrient requirement for their development and yield production, especially the modern improved variety as CNT1. The upland rice variety is usually grown under naturally drained soils with water supply through rainfall resulted in less well adapt for its productivity in the flooded condition may probably due to several reasons such as the adaptive of root zone condition and deep root system (Fageria, 2001). However, the ability for the uptake, translocation and accumulation of nutrients between rice varieties may probably depend on water and fertilizer management.
Nitrogen is a critical component in plants in the form of proteins, Adenosine Triphosphate (ATP), nucleic acids, amino acids and several plant hormones and it is also a component of chlorophyll as the pigment in the photosynthesis process (Takehisa et al., 2013). Therefore, $\mathrm{N}$ deficiency has been reported to substantially affect grain yield in rice (Yoshida, 1981; Nursu'aidah et al., 2014). This study found that foliar $\mathrm{N}$ improved the grain $\mathrm{N}$ concentration in CNT1, but not $\mathrm{KH} \mathrm{CMU}$ and the effect could be observed in the aerobic condition, but not in the flooded. This finding is supported by a previous report that total $\mathrm{N}$ uptake in rice crops grown in the aerobic soil could be enhanced by the provision of ammonium $\left(\mathrm{NH}_{4}\right)$ and nitrate $\left(\mathrm{NO}^{3-}\right)$ of the $\mathrm{N}$ fertilizer simultaneously which consequently had an effect on the grain $\mathrm{N}$ concentration (Trung and Koji, 1982; Qian et al., 2004). Thus, foliar N could effectively improve grain $\mathrm{N}$, especially when soil $\mathrm{N}$ is in limited supply such as in the aerobic growing condition which is a common practice in upland rice growing.

In contrast, the concentration of grain $\mathrm{P}$ in $\mathrm{KH} \mathrm{CMU}$ was higher when rice was grown in the flooded condition compared with the aerobic, but neither the water condition nor the fertilizer management was found to have an effect on grain P concentration in CNT1. On the other hand, grain $\mathrm{K}$ almost doubled in $\mathrm{KH} \mathrm{CMU}$ in comparison to CNT1 without any effect from either water or fertilizer managements. This reveals the contrasting behavior between the two rice varieties in accordance with the difference in their original ecotype. 
Phosphorus is an important component of DNA and RNA (Brown and Weselby, 2010) help to accelerate growth, spreading of roots and control of flowering and fruiting to create seeds (Rowley et al., 2012). The benefit of grain $\mathrm{P}$ in decreasing grain chalkiness and improving head milled rice, gel consistency and protein content has been reported (Hao et al., 2009; Zhang et al., 2012). Potassium helps in the synthesis of starch, sugar and protein and it promotes the movement of sugar from the leaves to the fruit (Pettigrew, 2008). Accumulation of potassium in the grain helps to increase aroma, whiteness and glossiness (Rohilla et al., 2000); accumulation of potassium also reduces the rate of chalky grains and increases the milling quality, amylose content and protein content (Bridgemohan and Bridgemohan, 2014; Thao et al., 2015). The results of this study indicate that upland rice adapted well to the flooded condition, which is not a common condition for its growing, but accumulated high grain $\mathrm{P}$, while higher grain $\mathrm{K}$ was found in upland rice independent of both water management and fertilizer management. As reported, rice roots are well modified to suit their morphological characteristics in the aerobic condition by the forming of stronger and longer root length to facilitate the uptake of water and nutrients, which is especially found in upland rice varieties (Colmer, 2003; Thang, 2006). Thus, this could be the reason for the better grain $\mathrm{P}$ and $\mathrm{K}$ accumulation in the $\mathrm{KH} C \mathrm{CMU}$ variety. However, the positive correlation between grain yield and grain P accumulation in CNT1 and grain yield and $\mathrm{Fe}$ concentration in $\mathrm{KH} \mathrm{CMU}$ indicating that higher grain $\mathrm{P}$ and $\mathrm{Fe}$ accumulation enhancing grain productivity in CNT1 and KH CMU, respectively. On the other hand, higher grain $\mathrm{N}, \mathrm{P}$ and $\mathrm{Zn}$ accumulation may result from the dilution effect from the lower grain yield in KH CMU as it was indicated by the negative correlation between grain yield and grain N, P and Zn concentration.

Along with being the key factor having an effect on grain yield and biochemical processes in plants, $\mathrm{N}$ is also found to affect the accumulation of other nutrients in plants such as Fe and Zn (Nantachan et al., 2016; Hao et al., 2007). This experiment found that foliar $N$ increased grain $\mathrm{Fe}$ and $\mathrm{Zn}$ concentrations when compared with no foliar N, especially in CNT1 grown under the aerobic condition, but that there was no effect in the flooded condition. The same was observed in previous studies that applying soil $\mathrm{N}$ fertilizer at 62.5 and $125 \mathrm{~kg} \mathrm{ha}^{-1}$ increased the grain $\mathrm{Zn}$ concentration by $11-42 \%$ among the rice varieties in northern Thailand (Nantachan et al., 2016). On the other hand, applying $\mathrm{N}$ at $62.5 \mathrm{~kg} \mathrm{ha}^{-1}$ increased the $\mathrm{Fe}$ accumulation in the leaf, husk and brown rice by $85.5 \%, 30.9 \%$ and $28.9 \%$, respectively and increased the grain $\mathrm{Zn}$ in brown rice from 16 to $20 \%$ when compared with no nitrogen application (Hao et al., 2007). In the aerobic condition, Fe availability is higher, in the range of acidic and neutral range soil $\mathrm{pH}$, but alkali soil has the serious problem of Fe deficiency. In addition, $\mathrm{Fe}$ and $\mathrm{Zn}$ uptake has been reported to be especially affected by redox-pH interaction and it has been observed that the uptake of the two elements decreased markedly as the $\mathrm{pH}$ was increased (Marschner, 2012). Foliar fertilizer application was carried out by spraying the fertilizer directly onto the leaf as it allows absorption to occur rapidly into the inner cell layers of the leaf and other reproductive organs (Ahmad and Jabeen, 2005; Ganapathy et al., 2008). It seems that the impact of foliar $\mathrm{N}$ fertilizer application on grain $\mathrm{Fe}$ and $\mathrm{Zn}$ can vary between the two selected varieties with variation in the ability of leaf absorption and seed deposition of foliar applied $\mathrm{Zn}$, which has been demonstrated in a previous study (Phattarakul et al., 2012).

\section{Conclusion}

The difference in responses between the two rice varieties representing their original ecotypes of upland and wetland is the key factor with respect to proper management of water and fertilizers in order to maximize grain yield and nutrition. Grain yield of wetland rice was independent from both the water and fertilizer managements, while it was reduced from the aerobic to flooded condition in upland rice. However, higher grain nutrient accumulation in rice could impact both seedling quality and intake of nutrition in rice consumers, which are affected by both variety as well as water and fertilizer managements. In the aerobic conditions, it may be required to make foliar $\mathrm{N}$ application a common practice while growing upland rice in order to improve the grain $\mathrm{N}$ concentration, but the same is not the case in the flooded conditions. At the same time, growing the upland rice variety in the flooded condition could result in higher grain $\mathrm{P}$ than growing it in the aerobic condition, but the same was not the response in wetland rice. Grain $\mathrm{K}$ was predominantly higher in upland rice than in wetland rice. Improving $\mathrm{Fe}$ and $\mathrm{Zn}$ accumulation in rice grains could be managed in wetland rice by foliar $\mathrm{N}$ application in aerobic growing conditions, but upland rice does not response the same. This knowledge is useful for proper management of water and fertilizers for improving grain yield and nutrient accumulation. However, in the future studies, increasing the number of rice varieties in each ecotype is needed to confirm the responses to water and fertilizer management in upland and wetland rice ecotypes.

\section{Acknowledgment}

We thank the National Research Council of Thailand, Thailand Research Fund (RSA6080024), the Functional Food Research Centre for Well-being and Graduate School, Chiang Mai University, Thailand for the financial support. 


\section{References}

Ahmad, R. and R. Jabeen, 2005. Foliar spray of mineral elements antagonistic to sodium-A technique to induce salt tolerance in plants growing under saline conditions. Pak. J. Bot., 37: 913-920.

Bremner, J.M. and C.S. Mulvaney, 1982. Nitrogen-Total. In: Methods of Soil Analysis, Part 2, Page, A.L. and C.S. Mulvaney (Eds.), American Society of Agronomy, Soil Science Society of America, Madison, Wisconsin, ISBN-10: 0891180729, pp: 595-624.

Bridgemohan, P. and R.S.H. Bridgemohan, 2014. Crop nutrition studies on grain filling and chalkiness in rice. J. Plant Breed. Crop. Sci., 6: 144-152. DOI: $10.5897 /$ JPBCS2014.0474

Brown, D. and C. Weselby, 2010. NASA-funded research discovers life built with toxic chemical. NASA Feature, Nasa.

Colmer, T.D., 2003. Aerenchyma and an inducible barrier to radial oxygen loss facilitate root aeration in upland, paddy and deep-water rice (Oryza sativa L.). Ann. Bot., 91: 301-309.

DOI: $10.1093 / \mathrm{aob} / \mathrm{mcfl} 14$

Comerford, N.B., 2005. Soil Factors Affecting Nutrient Bioavailability. In: Nutrient Acquisition by Plants: An Ecological Perspective, Bassirirad, H. (Ed.), ResearchGate, ISBN-10: 978-3-540-24186-7, pp:1-14.

Cruz, P.C., N.P. Banayo, S.R. Marundan, A.M. Magnaye and D.J. Lalican et al., 2012. Bio-inoculant and foliar fertilizer in combination with soil-applied fertilizer on the yield of lowland rice. Philips J. Crop. Sci., 37: 85-94.

Delhaiz, E., B. Dell, G. Kirk, J. Loneragan and R. Nable et al., 1984. Manual of Research Procedures. Plant Nutrition Research Group School of Environmental and Life Science, Murdoch University, Australia.

Fageria, N.K., 2001. Nutrient management for improving upland rice productivity and sustainability. Commun. Soil Sci. Plant Anal., 32: 2603-2629. DOI: $10.1081 / \mathrm{CSS}-120000394$

Fageria, N.K., M.B.B. Filho, A. Moreira and C.M. Guimarães, 2009. Foliar fertilization of crop plants. J. Plant Nutr., 32: 1044-1064. DOI: $10.1080 / 01904160902872826$

Ganapathy, M., G. Baradhan and N. Ramesh, 2008. Effect of foliar nutrition on reproductive efficiency and grain yield of rice fallow pulses. Legume Res. Int. J., 31: 142-144.

Hao, H.L., X.E. Yang, Y. Feng and C.Y. Wu, 2009. Effects of $\mathrm{P}$ fertilizer level on distribution of $\mathrm{Fe}$, $\mathrm{Mn}, \mathrm{Cu}$ and $\mathrm{Zn}$ in rice and brown rice qualities. Plant Nutr. Fer. Sci., 15: 1350-1356.

Hao, H.L., Y.Z. Wei, X.E. Yang, Y. Feng and C.Y. Wu, 2007. Effects of different nitrogen fertilizer levels on $\mathrm{Fe}, \mathrm{Mn}, \mathrm{Cu}$ and $\mathrm{Zn}$ concentrations in shoot and grain quality in rice (Oryza sativa). Rice Sci., 14: 289-294. DOI: 10.1016/S1672-6308(08)60007-4
Marschner, H., 2012. Marschner's Mineral Nutrition of Higher Plants. 3rd Edn., Academic Press, Amsterdam, Boston, MA, ISBN-10: 0123849063, pp: 672.

Moraghan, J.T. and H.J. Mascagni, 1991. Environmental and Soil Factors Affectingmicronutrient Deficiencies and Toxicities. In: Micronutrients in Agriculture, Luxmoore R.J. (Ed.), Soil Science Society of America, Madison, WI, pp: 371-425.

Nantachan, K., P. Jaksomsak, N. Panomjan and C. Prom-u-thai, 2016. Effect of nitrogen fertilizer on grain yield and zinc concentration in local rice varieties. Khon. Kaen. Agr. J., 44: 391-398.

Nursu'aidah, H., M.R. Motior, A.M. Nazia and M.A. Islam, 2014. Growth and photosynthetic responses of long bean (vigna unguiculata) and mung bean (vigna radiata) response to fertilization. J. Anim. Plant Sci., 24: 573-578.

Pettigrew, W.T., 2008. Potassium influences on yield and quality production for maize, wheat, soybean and cotton. Physiol. Plant, 133: 670-681. DOI: $10.1111 /$ j.1399-3054.2008.01073.x

Phattarakul, N., B. Rerkasem, L.J. Li, L.H. Wu and C.Q. Zou et al., 2012. Biofortification of rice grain with zinc through zinc fertilization in different countries. Plant Soil, 361: 131-141. DOI: 10.1007\%2Fs11104-012-1211-X

Qian, X., Q. Shen, G. Xu, J. Wang and M. Zhou, 2004. Nitrogen form effects on yield and nitrogen uptake of rice crop grown in aerobic soil. J. Plant Nutr., 27: 1061-1076. DOI: 10.1081/PLN-120037536

Rohilla, R., V.P. Singh, U.S. Singh, R.K. Singh and G.S. Khush, 2000. Crop husbandry and environmental factors affecting aroma and other quality traits. Aromatic Rices.

Rowley, S., G. Cardon and B. Black, 2012. Macronutrient management for Utah Orchards. USU Extension Publication Horticulture/Fruit/2012-01pr.

Islam, S.M., F. Rahman and A.T.M.S. Hossain, 2011. Effects of NPK briquette on rice (Oryza sativa) in tidal flooded ecosystem. Agriculturists, 9: 1-2. DOI: 10.3329/agric.v9i1-2.9477

Takehisa, H., Y. Sato, B.A. Antonio and Y. Nagamura, 2013. Global transcriptome profile of rice root in response to essential macronutrient deficiency. Plant Signal. Behav., 8: 1-7. DOI: 10.4161/psb.24409

Tejada, M. and J.L. Gonzalez, 2004. Effects of foliar application of a byproduct of the two-step olive oil mill process on rice yield. Eur. J. Agron., 21: 31-40. DOI: 10.1016/S1 161-0301(03)00059-5

Thang, D.H., 2006. Comparing growth, yield and nutrient uptake of rice in alternate aerated and anaerated condition. PhD. Thesis, Graduate School, Chiang Mai University, Thailand.

Thao, H.M., N.H. Hong, N.T. Tuyen, V.N. Toan and L.N. Quyen, 2015. Study on the effect of some of N, P, $\mathrm{K}$ fertilizer compounds on the yield and quality of Bp53 rice variety. J. Agric. Technol., 11: 2149-2156. 
Trung, C. and O. Koji, 1982. Effecfs of temperature and light intensity on the uptake and assimilation of ${ }^{15} \mathrm{~N}$ labeled ammonium and nitrate in Indica and Japonica rice plants. Soil Sci. Plant Nutr., 28: 91-98. DOI: 10.1080/00380768.1982.10432374

Watanabe, T., M. Osaki and T. Tadano, 1998. Effects of nitrogen source and aluminum on growth of tropical tree seedlings adapted to low pH soils. Soil Sci. Plant Nutr., 44: 655-666.

DOI: $10.1080 / 00380768.1998 .10414489$

Xiang, J., V.R. Haden, S. Peng, B.A.M. Bouman and R.M. Visperas et al., 2009. Improvement in nitrogen availability, nitrogen uptake and growth of aerobic rice following soil acidification. Soil Sci. Plant Nutr., 55: 705-714.

DOI: $10.1111 /$ j.1747-0765.2009.00407.x
Xu, X., P. He, S. Zhao, S. Qiu and A.M. Johnston et al., 2016. Quantification of yield gap and nutrient use efficiency of irrigated rice in China. Field. Crops Res., 186: 58-65. DOI: 10.1016/j.fcr.2015.11.011

Yoshida, S., 1981. Fundamantals of rice of crop science. The International Rice Research Insitute. Los Banos, Laguna, Philippines.

Zhang, Y.J., J.J. Hua, Y.C. Li, Y.Y. Chen and J.C. Yang, 2012. Effects of phosphorus on grain quality of upland and paddy rice under different cultivation. Rice Sci., 19: 135-142.

DOI: $10.1016 / \mathrm{S} 1672-6308(12) 60032-8$ 